\title{
Quality and safety of fish products in the Shuchinsk-Burabay Resort Zone')
}

\author{
BALGABAY S. MAIKANOV, LAURA T. AUTELEYEVA, GULZHIKHAN T. ISMAGULOVA, \\ JAN WIŚNIEWSKI*, ZBIGNIEW BEŁKOT**, KRZYSZTOF ANUSZ*
}

\author{
Veterinary Medicine and Technology of Animal Husbandry, \\ S. Seifullin Kazakh Agro Technical University, Zhenis Avenue 62, 010011 Nur-Sultan, Republic of Kazakhstan \\ *Department of Food Hygiene and Public Health Protection, Institute of Veterinary Medicine, \\ Warsaw University of Life Sciences (WULS-SGGW), Nowoursynowska 159, 02-776 Warsaw \\ **Department of Food Hygiene of Animal Origin, Faculty of Veterinary Medicine, \\ University of Life Sciences in Lublin, Akademicka 12, 20-950 Lublin
}

\section{Maikanov B. S., Auteleyeva L. T., Ismagulova G. T., Wiśniewski J., Bełkot Z., Anusz K. Quality and safety of fish products in the Shuchinsk-Burabay Resort Zone}

\section{Summary}

The aim of the study was to determine the nutritional value (content of endogenous and exogenous amino acids) and safety (content of metals and radionuclides) of the muscle tissue of fish obtained in the ShuchinskBurabay recreation area (Kazakhstan). Analytical methods involving mass spectrometry with inductively coupled plasma and liquid chromatography were used. The content of exogenous amino acids in fish protein was similar to their level in the meat of cattle, pigs, and poultry obtained in the same leisure zone. The ratio of the sum of exogenous amino acids to the sum of endogenous amino acids in fish meat protein ranged from 0.29 to 0.39. In all samples, it ranged from 45.45 to $33.33 \%$ of the norm. Samples of fish meat from some lakes diverged from the norm in the amount of exogenous and endogenous amino acids by $2.01-3 \%$. Valine was a limiting amino acid in the meat of fish from all lakes; its amount ranged from 21.6 to $27.8 \%$. The second most important limiting amino acid was isoleucine, which ranged from 72.1 to $77.25 \%$. The contents of heavy metal salts were up to $0.0590 \mathrm{mg} / \mathrm{kg}$ for arsenic, $0.0050 \mathrm{mg} / \mathrm{kg}$ for cadmium, and $0.0350 \mathrm{mg} / \mathrm{kg}$ for lead, which did not exceed the norms of the maximum allowable concentration of these metals. Only the mercury content in perch muscle tissue, which was $0.0385 \mathrm{mg} / \mathrm{kg}$, exceeded the maximum permissible concentration by $28 \%$. The level of other metals was in line with the standards. Fish from the lakes of the Shuchinsk-Burabay recreation area are slightly contaminated with heavy metal salts, but these pollutants generally do not exceed the maximum permissible concentration. The concentration of radionuclides in fish samples did not exceed the maximum permissible level.

Keywords: fish, amino acid composition, food safety, heavy metal salts, radionuclides

In the Republic of Kazakhstan, there are 16 resort zones, and one of the most popular is that of ShuchinskBurabay in the Akmola region. The Shuchinsk-Burabay resort zone is among the most famous and popular holiday destinations in the Republic of Kazakhstan, and it is of great importance for the development of tourism (23).

The Shuchinsk-Burabay resort zone includes objects of the nature reserve fund, mountains, lakes, dendrological parks, and dendrological arboretums.

1) This study was carried out as part of a project under the budget program 217 „Development of science” of the Ministry of Education and Science of the Republic of Kazakhstan for 2018-2020. No. AP05132302 on the topic "Issues of Shuchinsk-Burabay resort zone and the development of veterinary and sanitary measures".
The resort zone is a part of the Burabay State National Natural Park.

According to preliminary estimates, there are more than 170 sanatorium-resort and health-improving institutions and about 130 hotel complexes and tourist centers in the resort zone, with a total of about 12,000 beds. Given the characteristic food basket of Kazakhstanis, the most common products in the diet of vacationers in the resort zone are meat, fish, and honey. These foods are widely used in sanatoriums, rest homes, and public food outlets.

The most important element of the tourism infrastructure of the resort area is the catering sector, including restaurants, bars, cafes, coffee houses, cafeterias, canteens, snack bars, fast food systems, buffets, 
and cooking shops. Most of the catering services are included in the basic set of services provided by sanatorium-resort organizations. Catering organizations form an important part of the resort and recreational infrastructure. They are the basis for the integrated functioning and development of the entire industry (6).

Food products of both animal and plant origin, along with useful and necessary nutrients for the human body, can contain dangerous contaminants, such as toxic elements - cadmium, mercury, lead, zinc, as well as macronutrients in high concentrations. Food safety is an issue relevant for many countries, both developing and developed ones, especially in industrial and environmentally disadvantaged regions, as reported by many authors focusing on contaminants with carcinogenic properties $(3,8,17,21)$.

Contaminants are substances that inadvertently enter food products. Foreign substances can penetrate into food products at every stage in the food chain: during production, processing, storage, or transportation. They can also be ingested directly from the environment. The presence of such substances in food should be carefully monitored to avoid contamination that reduces the quality of food or its safety (http://www.fao.org/ fao-who-odexalimentarius/themes/contaminants/ru).

Therefore, over recent decades, there has been a growing interest in the presence of toxic metals in the aquatic environment and food products, especially fish, as well as in the contents of radionuclides in foods and the effect of technogenic contaminants on the nutritional value of foods (22).

The aim of this study was to determine the nutritional value and safety (as affected by the presence of heavy metal salts and radionuclides) of fish obtained and sold in the Shuchinsk-Burabay resort zone.

\section{Material and methods}

Fish samples were taken from the lakes of the Shuchinsk-Burabay resort zone: Burabay, Bolshoye Chebachye, Katarkol, Shchuchye. The fish samples (44 samples) were divided by species.

Sampling of fish was carried out in accordance with GOST 31339-2006 "Fish, non-fish objects and products from them. Acceptance rules and sampling methods".

All chemical reagents were of good analytical quality and had been purchased from Sigma-Aldrich (Merck KGaA, Darmstadt, Germany).

The heavy metal salts in the products were investigated by inductively coupled plasma mass spectrometry. The standard operating procedure "Determination of trace elements.
Determination of arsenic, cadmium, mercury and lead in food by inductively coupled plasma mass spectrometry (ICP-MS) after pressure mineralization by Agilent Technologies 7700 Series ICP-VS IC-SOP-M-E-002" was developed to conduct this study in the Laboratory of Food Safety of RSE at RCEA "NRCV" Ministry of Agriculture of the Republic of Kazakhstan. This procedure was developed and tested on the basis of British GOST BS EN 15763: 2009. The procedure was designed to determine trace elements (arsenic, cadmium, lead and mercury) in food products by inductively coupled plasma mass spectrometry, with measurement ranges of $0.06-21.5 \mathrm{mg} / \mathrm{kg}$ for As, $0.03-28.3 \mathrm{mg} / \mathrm{kg}$ for $\mathrm{Cd}, 0.04-0.56 \mathrm{mg} / \mathrm{kg}$ for $\mathrm{Hg}$, and $0.01-2.4 \mathrm{mg} / \mathrm{kg}$ for $\mathrm{Pb}$. The maximum permissible concentration (MPC) of the tested elements was determined.

Sampling for measuring the content of radionuclides was carried out according to GOST 32164 "Sampling for research on radionuclides." The tests were carried out using the spectrometric complex Progress in accordance with the Interstate Standard GOST 32161-2013 "Food Products. Method for determination of cesium-137 content" and GOST RK "Radiation control. Strontium-90 and cesium137. Food products. Sampling, analysis and hygienic assessment."

Amino acid composition was determined in accordance with GOST 34132-2017 "Meat and meat products. Method for determining the amino acid composition of animal protein." The study was carried out on a liquid chromatograph SHIMADZULC-20 Prominence (Japan).
Tab. 1. Amino acid composition of fish meat protein $\mathbf{g} \cdot \mathbf{k g}^{-1}$

\begin{tabular}{|c|c|c|c|c|c|}
\hline \multirow{2}{*}{ Indicators } & \multicolumn{4}{|c|}{ Reservoirs/Fish species } & \multirow{2}{*}{ Norm } \\
\hline & Shuchye (rudd) & Kypshakty (carp) & Borovoye (rudd) & Katarkol (crucian) & \\
\hline \multicolumn{6}{|c|}{ Exogenous amino acids } \\
\hline Valine & $221.97 \pm 0.04$ & $198.77 \pm 0.07$ & $211.00 \pm 0.01$ & $172.87 \pm 0.01$ & 1100 \\
\hline Isoleucine & $495.59 \pm 0.02$ & $475.90 \pm 0.04$ & $462.39 \pm 0.01$ & $461.38 \pm 0.05$ & 800 \\
\hline Leucine & $1479.66 \pm 0.004$ & $1355.56 \pm 0.02$ & $1399.05 \pm 0.02$ & $1307.79 \pm 0.01$ & 1800 \\
\hline Lysine & $453.41 \pm 0.04$ & $467.65 \pm 0.05$ & $444.40 \pm 0.01$ & $451.60 \pm 0.01$ & 1900 \\
\hline Methionine & $577.84 \pm 0.01$ & $507.17 \pm 0.04$ & $573.36 \pm 0.02$ & $527.82 \pm 0.02$ & 500 \\
\hline Threonine & $1075.71 \pm 0.01$ & $878.68 \pm 0.04$ & $972.22 \pm 0.03$ & $785.41 \pm 0.02$ & 900 \\
\hline Tryptophan & $220.10 \pm 0.02$ & $274.88 \pm 0.09$ & $209.99 \pm 0.04$ & $286.05 \pm 0.01$ & 180 \\
\hline Phenylalanine & $532.26 \pm 0.03$ & $471.36 \pm 0.02$ & $505.51 \pm 0.02$ & $448.37 \pm 0.02$ & 800 \\
\hline Total & 5056.54 & 3751.29 & 4777.92 & 4441.29 & 7980 \\
\hline \multicolumn{6}{|c|}{ Endogenous amino acids } \\
\hline Arginine & $1597.75 \pm 0.02$ & $1306.32 \pm 0.01$ & $1347.16 \pm 0.02$ & $1285.71 \pm 0.01$ & 900 \\
\hline Alanine & $841.70 \pm 0.02$ & $765.59 \pm 0.02$ & $787.95 \pm 0.01$ & $737.68 \pm 0.02$ & 1000 \\
\hline Tyrosine & $2069.56 \pm 0.05$ & $1740.41 \pm 0.01$ & $1847.58 \pm 0.02$ & $1624.77 \pm 0.02$ & 500 \\
\hline Cysteine & $378.69 \pm 0.01$ & $342.58 \pm 0.04$ & $360.53 \pm 0.02$ & $334.65 \pm 0.04$ & 150 \\
\hline Aspartic acid & $2810.48 \pm 0.01$ & $2596.07 \pm 0.01$ & $2681.39 \pm 0.05$ & $2614.15 \pm 0.05$ & 1700 \\
\hline Glutamic acid & $3332.30 \pm 0.02$ & $3223.94 \pm 0.05$ & $291.19 \pm 0.02$ & $3272.15 \pm 0.02$ & 2700 \\
\hline Serine & $1042.93 \pm 0.06$ & $902.35 \pm 0.05$ & $943.05 \pm 0.02$ & $880.68 \pm 0.04$ & 800 \\
\hline Glycine & $286.49 \pm 0.02$ & $235.04 \pm 0.07$ & $291.19 \pm 0.02$ & $208.87 \pm 0.03$ & 600 \\
\hline Proline & $606.32 \pm 0.03$ & $92.93 \pm 0.08$ & $474.47 \pm 0.01$ & $158.70 \pm 0.01$ & 500 \\
\hline Histidine & $287.82 \pm 0.004$ & $458.13 \pm 0.05$ & $274.60 \pm 0.01$ & $334.65 \pm 0.02$ & 300 \\
\hline Total & 13707.47 & 13009.71 & 12671.08 & 12045.71 & 9150 \\
\hline
\end{tabular}




\section{Results and discussion}

Table 1 shows the amino acid content of fish meat protein. In the proteins of fish meat samples from all lakes, the limiting amino acids were valine: from 172.87 to $221.97 \mathrm{mg} / 100 \mathrm{~g}$, which is from 15.7 to $20.2 \%$ of the norm, lysine: from 451.60 to $467.65 \mathrm{mg} / 100 \mathrm{~g}$ (23.4$-24.6 \%$ ), isoleucine: from 461.38 to $495.59 \mathrm{mg} / 100 \mathrm{~g}$ (57.7-61.9\%), phenylalanine: from 448.37 to 532.26 $\mathrm{mg} / 100 \mathrm{~g}$ (56-66.5\%), and leucine: from 1307.79 to $1479.66 \mathrm{mg} / 100 \mathrm{~g}(72.7-82.2 \%)$. The amino acid composition is determined in various animal and plant matrices. Mandume et al. (14) determined the nutritional value of the meat of Chaceon maritae. The results showed that the protein of Chaceon maritae is of high quality and can be considered a good source of irreplaceable amino acids. The content of irreplaceable amino acids higher than in the reference amino acid structure may be useful for supplementing low-quality proteins from other food sources.

Khazaei et al. (11) examined the amino acid composition of lentil protein and concluded that lentil protein has a low level of irreplaceable amino acids compared to that of replaceable amino acids. Chen et al. (5) studied the nutritional value of Camellia sinensis black tea and concluded that the amount of amino acids in black tea decreases when tea is fermented in the production process. Kandyliari et al. (10) determined the nutrient composition and nutritional value of fish and fish products and found that fish by-products that are traditionally disposed of contain irreplaceable amino acids, minerals, and vitamins, as well as muscle tissue.

Table 2 shows the ratio of irreplaceable to replaceable amino acids in fish meat protein, ranging from 0.29 to 0.39 . The ratio in all samples was $45.45 \%$ to $33.33 \%$ of the norm. Data show that samples from some lakes diverged from the norm in the amount of amino acids by 2.01 to $3 \%$.

Table 3 . When determining the nutritional value of fish meat protein on a standard scale of an referens protein, valine was found to be the limiting amino acid in the protein of fish meat from all lakes: its indices ranged from 21.6 to $27.8 \%$. The second most important limiting amino acid was isoleucine, which ranged from 72.1 to $77.25 \%$.

A similar result for valine as a limiting amino acid in Grass carp protein was also obtained by other authors (18).

According to the results of the present study, the proteins are deficient in valine (60-62\%), isoleucine (59-79\%), tryptophan (42-63\%), and phenylalanine (76-81\%), although they contain more lysine and methionine (13).

When determining the exogenous amino acids rates, value of valine and isoleucine were below normal in the proteins of all fish meat samples. The remaining irreplaceable amino acids exceeded the norm by $20-70 \%$.

As shown in Table 4, the contents of heavy metal salts in fish samples were up to $0.0590 \mathrm{mg} / \mathrm{kg}$ for arsenic, $0.0050 \mathrm{mg} / \mathrm{kg}$ for cadmium, and $0.0350 \mathrm{mg} / \mathrm{kg}$ for lead, none of which exceeds the norms of the maximum permissible concentration of heavy metals adopted in the Republic of Kazakhstan.

The mercury content in perch samples exceeded the maximum permissible concentration by $28 \%$, whereas mercury concentration in the other fish samples was not higher than $0.07 \mathrm{mg} / \mathrm{kg}$.

Fish from the lakes of the Shuchinsk-Burabay resort zone are contaminated with salts of heavy metals, which, however, do not exceed the maximum permissible concentrations, except for mercury in some tissues of certain fish species.

The results of the analysis of heavy metal salts in the fish samples show that trace concentrations of arsenic, cadmium, and lead were present in all samples, but

Tab. 2. Ratio of irreplaceable to replaceable amino acids in fish meat protein

\begin{tabular}{|l|c|c|c|c|}
\hline \multicolumn{1}{|c|}{ Indicators } & \multicolumn{4}{|c|}{ Reservoirs/Fish species } \\
& $\begin{array}{c}\text { Shuchye } \\
\text { (rudd) }\end{array}$ & $\begin{array}{c}\text { Kypshakty } \\
\text { (carp) }\end{array}$ & $\begin{array}{c}\text { Borovoye } \\
\text { (rudd) }\end{array}$ & $\begin{array}{c}\text { Katarkol } \\
\text { (crucian) }\end{array}$ \\
\hline $\begin{array}{l}\text { Ratio of the sum of exogenous } \\
\text { to endogenous amino acids }\end{array}$ & 0.36 & 0.29 & 0.38 & 0.36 \\
\hline Total sum of amino acids & 18764.01 & 16761 & 17449 & 16487 \\
\hline
\end{tabular}

Tab. 3. Exogenous amino acids rate of fish meat protein (\%)

\begin{tabular}{|c|c|c|c|c|}
\hline \multirow[b]{2}{*}{ Indicators } & \multicolumn{4}{|c|}{ Reservoirs/Fish species } \\
\hline & $\begin{array}{l}\text { Shuchye } \\
\text { (rudd) }\end{array}$ & $\begin{array}{l}\text { Kypshakty } \\
\text { (carp) }\end{array}$ & $\begin{array}{c}\text { Borovoye } \\
\text { (rudd) }\end{array}$ & $\begin{array}{l}\text { Katarkol } \\
\text { (crucian) }\end{array}$ \\
\hline Valine & 27.8 & 24.8 & 26.4 & 21.6 \\
\hline Isoleucine & 77.25 & 74.4 & 72.2 & 72.1 \\
\hline Leucine & 132.1 & 121 & 125 & 116.8 \\
\hline Methionine + cystine & 170.8 & 151.7 & 166.8 & 154 \\
\hline Threonine & 168 & 137.3 & 152 & 122.7 \\
\hline Tryptophan & 138 & 171.8 & 131.2 & 178.8 \\
\hline Phenylalanine + tyrosine & 271 & 230.4 & 245.1 & 216 \\
\hline
\end{tabular}
most valuable protein was that of fish meat from Lake Shuchye. The contents of valine, isoleucine, leucine, and phenylalanine were higher than they were in other samples. In terms of the composition and ratio of irreplaceable amino acids, proteins of fish and meat are even more different from the reference protein than human milk is, which is caused by the peculiarity of the amino acid composition of muscle tissue proteins. These

Tab. 4. Average contents of heavy metal salts in fish (mg/kg)

\begin{tabular}{|l|c|c|c|c|}
\hline \multirow{2}{*}{ Fish (n) } & As & Cd & $\mathrm{Hg}$ & $\mathrm{Pb}$ \\
& 0.1 & 0.05 & 0.03 & 0.5 \\
\hline Carp (8) & $0.0167 \pm 0.0083$ & 0 & $0.0201 \pm 0.0100$ & $0.0257 \pm 0.0110$ \\
Rudd (12) & $0.0590 \pm 0.0147$ & 0 & $0.0250 \pm 0.0043$ & $0.0350 \pm 0.0043$ \\
Perch (17) & $0.0305 \pm 0.0056$ & $0.0050 \pm 0.0014$ & $0.0385 \pm 0.0062$ & $0.0250 \pm 0.0014$ \\
Crucian (4) & $0.0600 \pm 0.0040$ & 0 & $0.0070 \pm 0.0090$ & $0.0100 \pm 0.0004$ \\
\hline
\end{tabular}


did not exceed the norm. In the samples from perch, the concentration of mercury exceeded the maximum permissible level. The accumulation of heavy metal salts in fish tissues occurs due to the presence of heavy metal salts in water. The consumption of such fish can be harmful to human health. These data are confirmed by other scientists $(4,9,15)$. In this study, only the muscles of fish were used. The content of heavy metal salts in other tissues was not determined. However, the bioaccumulation value is a species-specific function for trophic transfer (20).

Scientists from various countries have been conducting extensive studies to determine the salts of heavy metals, radionuclides and nutritional value in various matrices. For example, Parengam et al. (16) found $\mathrm{Cd}$ and $\mathrm{Pb}$ in rice sold in Thailand. In 2017, Abtahi et al. (1) found $\mathrm{As}, \mathrm{Cr}, \mathrm{Cd}, \mathrm{Ni}$, and $\mathrm{Pb}$ in rice grown in Iran, the results showing an excess of the hazard coefficient for consumers. Lanreiyanda and Adekunle (12) analyzed the content of $\mathrm{As}, \mathrm{Cd}, \mathrm{Cu}, \mathrm{Ni}, \mathrm{Pb}$, and $\mathrm{Zn}$ in food sold in Nigeria, whereas Ali and Al-Kahtani (2) examined the contents of $\mathrm{Cd}, \mathrm{Cu}, \mathrm{Fe}, \mathrm{Hg}, \mathrm{Mn}, \mathrm{Pb}$, and $\mathrm{Zn}$ in vegetables sold in Saudi Arabia. Gupta et al. (7) investigated the contents of heavy metals in vegetables irrigated with wastewater and found that the contents of $\mathrm{Cd}, \mathrm{Cr}, \mathrm{Pb}$, and $\mathrm{Zn}$ in those vegetables exceeded the maximum permissible concentrations defined by China's national food safety standard. Rahmani et al. (19) analyzed the content of twelve metals in canned tuna in Iran and assessed the resulting risk to human health.

Table 5 shows that the level of cesium-137 did not exceed the maximum permissible level in any of the fish samples, amounting to $32.30 \mathrm{~Bq} / \mathrm{kg}$ in cisco, $33.65 \mathrm{~Bq} /$ $\mathrm{kg}$ in carp, $32.7 \mathrm{~Bq} / \mathrm{kg}$ in rudd, $32.85 \mathrm{~Bq} / \mathrm{kg}$ in perch, $46.25 \mathrm{~Bq} / \mathrm{kg}$ in peled, and $32.5 \mathrm{~Bq} / \mathrm{kg}$ in crucian.

In none of the samples of agricultural products, the activity of cesium- 137 exceeded the maximum permissible level, which indicates that the resort zone is safe with regards to radionuclides. There are no heavy industry enterprises in the Shuchinsk-Burabay resort zone, nor is there any rock mining in progress.

The quality of the fish samples from the resort zone was reduced by the low contents of the following irreplaceable amino acids: valine, lysine, isoleucine, and phenylalanine. Valine and isoleucine were the amino acids limiting the biological value of fish protein. The concentration of heavy metals and radionuclides in the samples of fish did not exceed the maximum permissible concentration, with the exception of mercury.

Tab. 5. Average cesium-137 activity in fish (Bq/kg)

\begin{tabular}{|l|c|c|}
\hline \multicolumn{1}{|c|}{ Fish (n) } & Research results & Permissible level \\
\hline Cisco (2) & $32.30 \pm 0.0577$ & 130 \\
Carp (8) & $33.65 \pm 0.1588$ & 130 \\
\hline Rudd (12) & $32.70 \pm 0.4330$ & 130 \\
Perch (17) & $32.85 \pm 0.0722$ & 130 \\
\hline Peled (1) & $46.25 \pm 0.4230$ & 130 \\
Crucian (4) & $32.50 \pm 0.2598$ & 130 \\
\hline
\end{tabular}

\section{References}

1. Abtahi M., Fakhri Y., Conti G., Keramati H., Zandsalimi Y., Bahmani Z., Pouya R., et al.: Heavy metals (As, $\mathrm{Cr}, \mathrm{Pb}, \mathrm{Cd}$ and $\mathrm{Ni}$ ) concentrations in rice (Oryza sativa) from Iran and associated risk assessment: a systematic review. Toxin Rev. 2017, 36, 331-341.

2. Ali M., Al-Qahtani K.:Assessment of some heavy metals in vegetables, cereals and fruits in Saudi Arabian markets. Egypt. J. Aquat. Res. 2012, 38, 31-37.

3. Baldji Yu. A., Adilbekov $\mathrm{Zh}$. Sh.: Modern aspects of quality control and food safety. «Lan» publishing house St. Petersburg, Russian Federation 2019, C. 6.

4. Begum A., Mustafa A. I., Amin M. N., Chowdhury T. R., Quraishi S. B., Banu N.: Levels of heavy metals in tissues of shingi fish (Heteropneustes fossilis) from Buriganga River, Bangladesh. Environ. Monit. Assess. 2013, 185, 5461-5469.

5. Chen Y., Zeng L., Liao Y., Li J., Zhou B., Yang Z., Tang J.: Enzymatic reactionrelated protein degradation and proteinaceous amino acid metabolism during the black tea (Camellia sinensis) manufacturing process. Foods 2020, 9, 66 .

6. Dzhum T. A., Zadneprovskaya E. L., Polzikova E. V.: Analysis of the development of catering in the resort territories of the Krasnodar Territory. Marketing services and territories. 2018, 80, 91-92.

7. Gupta N., Khan D., Santra S.: Heavy metal accumulation in vegetables grown in a long-term wastewater-irrigated agricultural land of tropical India. Environ. Monit. Assess. 2012, 184, 6673-6682.

8. Islam M. S.: The concentration, source and potential human health risk of heavy metals in the commonly consumed foods in Bangladesh. Ecotoxicol. Environ. Safety 2015, 122, 462-469.

9. Javed M., Usmani N.: Assessment of heavy metal (Cu, Ni, Fe, Co, Mn, Cr, $\mathrm{Zn}$ ) pollution in effluent dominated rivulet water and their effect on glycogen metabolism and histology of Mastacembelus armatus. Springer Plus 2013, 2, 390 .

10. Kandyliari A., Mallouchos A., Papandroulakis N., Golla J. P., Lam T. T., Sakellari A., Karavoltsos S., Vasiliou V., Kapsokefalou M.: Nutrient composition and fatty acid and protein profiles of selected fish by-products. Foods 2020, 9, 190

11. Khazaei H., Subedi M., Nickerson M., Martinez-Villaluenga C., Frias J., Vandenberg A.: Seed protein of lentils: current status, progress, and food applications. Foods 2019, 8, 391 .

12. Lanreiyanda T., Adekunle I.: Assessment of heavy metals and their estimated daily intakes from two commonly consumed foods (kulikuli and Robo) found in Nigeria. Afr. J. Food Agric. Nutr. Dev. 2012, 12, 6156-6169.

13. Lysikov Yu. A.: Amino acids in human nutrition. Exp. Clin. Gastroenterol. 2012, 2, 88-105.

14. Mandume C. M. C., Bandarra N. M., Raimundo J., Lourenço H. M., Gonçalves S., Ventura M., Delgado I., Rego A., Motta C., Castanheira I., Nunes M. L., Duarte M. P.: Chemical composition, nutritional value, and safety of cooked female Chaceon Maritae from Namibe (Angola). Foods 2019, 8, 227.

15. Maurya P. K., Malik D. S., Yadav K. K., Kumar A., Kumar S., Kamyab H. Bioaccumulation and potential sources of heavy metal contamination in fish species in River Ganga basin: Possible human health risks evaluation. Toxicol. Rep. 2019, 6, 472-481.

16. Parengam M., Judprason, K., Srianujata $S$., et al.: Study of nutrients and toxic minerals in rice and legumes by instrumental neutron activation analysis and graphite furnace atomic absorption spectrophotometry. J. Food Comp. Anal. 2010, 23, 340-345.

17. Pilarczyk R.: Concentrations of Toxic and Nutritional Essential Elements in Meat from Different Beef Breeds Reared under Intensive Production Systems. Biol. Trace Element Res. 2014, 158, 36-44.

18. Pyz-Lukasik R., Paszkiewicz W.: Species variations in the proximate composition, amino acid profile, and protein quality of the muscle tissue of grass carp, bighead carp, Siberian sturgeon, and wells catfish. J. Food Qual. 2018, 2, 1-8, doi 10.1155/2018/2625401.

19. Rahmani J., Fakhri Y., Shahsavani A.: A systematic review and meta-analysis of metal concentrations in canned tuna fish in Iran and human health risk assessment. Food Chem. Toxicol. 2018, 118, 753-765

20. Spry D. J., Wiener J. G.: Metal bioavailability and toxicity to fish in lowalkalinity lakes - a critical review. Environ. Pollut.1991, 71, 243-244.

21. Tang J.: Exposure assessment of heavy metals $(\mathrm{Cd}, \mathrm{Hg}$, and $\mathrm{Pb})$ by the intake of local foods from Zhejiang, China. Environ. Geochem. Health 2014, 36, 765-771.

22. Wong M. H., Hung K. M., Chiu S. T.: Sludge-growth algae for culturing aquatic organisms. Part II. Sludge-growth algae as foods for aquatic organism. Environ. Manage. 1996, 20, 375-384.

23. Yushina Y. A., Orazbekov K. C.: Evaluation of tourist-recreational capacity lake Shchuchinsky-Borovsky resorts zone. Science, New Technologies and Innovations of Kyrgyzstan 2019, 9, 120-124.

Corresponding author: Zbigniew Bełkot DVM, PhD, ul. Akademicka 12, 20-033 Lublin; e-mail: zbigniew.belkot@up.lublin.pl 